\title{
Investigation of the Relationship between University Students' Learning Strategies and their Autonomy
}

\author{
Marwa Mourad Saleh \\ Assistant lecturer of curricula and English instruction
}

Fayoum University

Prof. Mohammed Farouk Abd El Samie

Professor of curriculum and English instruction

Vice dean of post graduate studies and research

Fayoum University
Dr. Mona Ahmed Abd El Tawab

Lecturer of curriculum and English

instructio

Fayoum University

\section{Abstract}

4th year Faculty of Education English majors' are taught academic as well as educational courses. One of the main aims of the learning process in faculty is to help learners to be autonomous ones because this will enable them to depend on themselves to update their information. So, many courses should be designed to develop learners' autonomy. The current study aims at investigating the relationships between the learning strategies 4th year Faculty of Education English majors' use and their autonomy. The participants of the study were 100 male and female students enrolled in the 4th year in Faculty of Education, 
Fayoum University in the first semester of the academic year 2014-2015.The study instrument were a learning strategies questionnaire and learner autonomy questionnaire. Biserial correlation coefficient was used to deal with the study statistics. Results indicated that sophisticated strategies users showed a strong correlation coefficient in all autonomy components especially responsibility, reflection and activation of independent strategies. The study presents suggested some topics for further research in the light of the study results.

Key words :language strategies and autonomy

\section{Introduction:}

Autonomy is an essential characteristic for a good language leaner. Especially for those who learn a language as a foreign language do not have the opportunity to hear or use the language in the real world. Therefore, it is their own responsibility to create and be in environments where the target language is used. Although language teachers or professional consultants may help the learner, he should be responsible for his own learning (Bayat , 2008: 8). "Not matter what the teacher does or what the course book presents, ultimately it is the learner who does the learning. The more learners are aware of 
how learning is best carried out, the better learning is likely to be" ( Nation , 1998: 9).

The basis of learner autonomy is that the learner accepts responsibility of his or her learning. This acceptance of responsibility has both socio - affective and cognitive implications: it entails at once a positive attitude to learning and the development of a capacity to reflect on the content and process of learning with a view to bringing them as far as possible under conscious control (Little : 1995: 175).

Although researchers have recently discovered and named language learning strategies, such strategies have actually been used for thousands of years (Oxford, 1990:1). Language learning strategies are of a great help for both language learners and teachers. Since the amount of information to be processed by language learners is high in language classroom, learners use different language learning strategies in performing the tasks and processing the new input they face. Language learning strategies give language teachers valuable clues about how their students assess the situation, plan, select appropriate skills to understand, learn, or remember new input presented in the language classroom (Hismanoglu,2000:10). 
Successful language learners need to make use of a wide variety of learning strategies (Chamot, 2004: 20). The language learner who is able to use different types of language learning strategies appropriately can improve his language skills (Fedderholdt, 1998:14). According to Oxford (1990:1) language learning strategies are important for language learners as they are valuable tools for self-directed movement that is essential in improving communicative competence.

The literature on learning strategies and learner training currently aimed at developing autonomy in language learners ( Little , 1995: 177). Learners' making use of language learning strategies is a key step in gaining autonomy as they will understand and evaluate their own learning process and will be able to exert some control over these processes, which will result in becoming more responsible for their own learning and taking charge of their own learning strategies are important cornerstones on the path to autonomy (Nalkensen and Ozek, 2011: 164).

\section{Statement of the problem}

It is obvious from the previous introduction that learners' use of learning strategies affects their autonomy. The current study 
attempts to investigate the learning strategies used by 4 th year Faculty of Education English majors and the relationships between these strategies and the autonomy components. In other words, this study attempts to trace how good learners behave, how much autonomy they have and the driving force of this autonomy. The study will try to answer the following main question:

What types of strategies 4th year Faculty of Education English majors' have and how these strategies correlate to their autonomy?

This major question is branched out into the following subquestions:

What is the relationship between 4th year Faculty of Education English majors' use of learning strategies (naive vs. ) and their :

1-responsibility?

2-reflection?

3-self-esteem?

4-activation of independent learning strategies? 
5-self-assessment?

6-self-empowerment?

\section{Significance of the study}

The current study may help in identifying the learning strategies of good learners and their various of their characteristics can help in establishing stereotypes for the required learners our schools and colleges should graduate. Also, it aims to raise learners' awareness of their inner abilities and strategies.

\section{Hypotheses of the study}

The hypotheses of the present study are the following:

1- There are significant statistical differences between means of scores obtained by the naive and strategies users in autonomy in favour of the strategies users .

2- There are significant statistical differences between means of scores obtained by the naive and strategies users in responsibility component in favour of the strategies users.

3- There are significant statistical differences between means of scores obtained by the naive and strategies 
users in reflection component in favour of the complicated strategies users.

4- There are significant statistical differences between means of scores obtained by the naive and strategies users in self-esteem component in favour of the strategies users.

5- There are significant statistical differences between means of scores obtained by the naive and strategies users in activation of independent learning strategies component in favour of the strategies users.

6- There are significant statistical differences between means of scores obtained by the naive and strategies users in self-assessment component in favour of the strategies users.

7- There are significant statistical differences between means of scores obtained by the naive and strategies users in self-empowerment component in favour of the strategies users.

\section{Delimitations of the study:}

The study will be delimited to 100 Egyptian English majors at Faculty of Education, Fayoum University.100 students enrolled 
in the fourth years in the first semester of the academic year 2014-2015.

\section{Definition of terms:}

The researcher adopted the following definitions in the current study:

\section{Learning strategies}

Oxford (1990: 8) defines learning strategies as" specific actions taken by the learner to make learning easier, faster, more enjoyable, more self- directed, more effective, and more transferable to new situations".

\section{Autonomy}

Boud (1995)defines autonomy as the capacity of learner to" take some significant responsibility for their own learning".

\section{Review of literature}

The use of learning strategies is essential for language learners as metacognitive strategies improve organization of learning time, sef-monitoring and self-evaluation. In addition, cognitive strategies help learners to use previous knowledge to solve new problems. Also, socio-affective strategies encourage learners to ask native speakers to correct their pronunciation, or

\section{r.}


ask a classmate to work together on a particular language problem (Fedderholdt, 1998:14).

A number of attempts have been made to develop taxonomies of learning strategies. The most famous taxonomy of learning strategies in the field of foreign language learning is Oxford's one. It includes the following strategies:

*Direct strategies

1-Memory strategies

A. Creating mental linkages

B. Applying images and sounds

C. Reviewing well

D. Implying action

2-Congnitive strategies
A. Practicing
B. Receiving and sending messages
C. Analyzing and reasoning
D. Creating structure for input and output 


\section{3-Compensation strategies}

A. Guessing intelligently

B. Overcoming limitations in speaking and writing.

*Indirect strategies

1-Metacognitive strategies
A. Centering your learning
B. Arranging and planning your learning
C. Evaluating your learning

2-Affective strategies
A. Lowering your anxiety
B. Encouraging yourself
C. Taking your emotional temperature

3-Social strategies
A. Asking questions
B. Cooperating with others
C. Empathizing with others. 
According to Oxford (1990:1) language learning strategies usually contribute to autonomous learning. Wenden (1991:15) states that one of the characteristics of autonomous learners is their ability to apply learning strategies properly and independently. Rubin (1987) states that using effective learning strategies helps learners to learn independently or autonomously (Tassana-ngam, 2004: 60). The better understanding of language learning strategies for English teachers can help students to learn more successfully and develop their learning autonomy ( Lee , $2010: 132)$

According to Jones ( 1998) and Yamato (2000) metacognitive and cognitive strategy use is a main "key" for students to become more independent and responsible for their own learning; therefore, learners should be encouraged to individualize their strategy use, which may vary based on educational, linguistic or cultural background and learning style (Griva, Kamaroudis and Geladari , 2009: 23). Metacognitive knowledge is crucial for helping students make conscious, directed, autonomous and efficient use of strategies (Mercer, 2005: 26). Students with greater metacognitive awareness understand the similarity between the current learning task and previous ones, know the strategies required for successful learning, and anticipate success 
as a result of knowing "how to learn" (Chamot, Keatley, Meloni, Ggonglewski and Bartoshesky n.d.: 1).

$\mathrm{Gu}$ and Johnson (1996:664) indicate that successful strategy users need a strategy for controlling their strategy use. This involves choosing the most appropriate strategy from a range of known options and deciding how to pursue the strategy and when to switch to another strategy. Ideally, learners should be made aware of "good' efficient strategies so that they could freely and consciously choose the one(s) suitable for them.

Despite the fact that the link between learning strategies and learner autonomy is very close, further research is still needed to figure out how much the learning strategies students use correlate to their autonomy. Little (1995) summarizes the relationship between learning strategies and autonomy stating that focusing on the strategic capability of language learning and language use should lead us to learner autonomy, the reverse should also be the case: focus on strategies should lead us to learner autonomy.

One of the leading goals of the research on second language teaching is an autonomous language learner ( Codesal , 2000: 174). To be an autonomous learner is to have the ability to make 
decisions for one's own learning . To have the ability to set goals, implement strategies to attain goals, identify relevant resources, and access personal progress (Aliponga , Gamble and Ando , 90). In other words, autonomous learners are able to manage :

1- The planning of their learning.

2- Its organization and

3- Its evaluation (De Florio - Hansen, nd: 34).

According to Dickinson (1993) autonomous learners have five characteristics. First, autonomous learners are aware of the learning material, its goal and why the teacher does particular activities in the classroom. Second, they are able to set their own goals. Third, they are the individuals who choose and practice appropriate learning strategies. They know which strategies are more effective for them. Forth they use particular strategies. For example, autonomous language learners know how to make of use of any kind of clues which may support a text written in a foreign language before reading all of it. They make use of pictures, titles and captions. They relate all this information with their previous knowledge. They ask themselves questions about the text before reading it. Finally, autonomous learners are capable of self-assessing their performance (Bayat, 2008:8). 
Being autonomous learners do not necessarily mean that they study alone. It is possible to be an autonomous learner in a strongly teacher - led class, by deciding what should be given the greatest attention and effort, what should be looked at again outside class, how the material presented should be mentally processes, and how interaction with the teacher and others in the class should be carried out(Nation, 1998: 9).

Autonomy depends on three factors - attitude, awareness, and capability. Attitudes refer to the need for the learner to want to take control and responsibility for learning. This is one of the hardest aspects of autonomy to develop and yet it is the most crucial. Awareness refers to the need for the learner to be conscious of what approaches are being taken, to reflect on their effects, and to consider other approaches. Capability refers to the need for the learner to posses the skills and knowledge to be autonomous in a particular area of study Nation (1998: 9).

Beson (2001 ) distinguishes between six main approaches to learner autonomy:

(1) resource - based approaches,

(2) technology - bases approaches,

(3) learner - based approaches. 
(4) classroom - based approaches.

(5) curriculum - based approaches,

(6) teacher - based approaches.

The first two approaches rely on CALL (Computer Assisted Language Learning) and CMC (Computer Mediated Communication) via the internet. Both approaches provide the learners with opportunities to self - direct their own learning. Learner - based approaches place the main emphasis on behavioral and psychological changes that enable learners to take greater control of their learning and thus help them become better language learners. Classroom - based approaches put the emphasis on changes in the relationships within conventional educational structures. Curriculum based approaches focus on process syllabuses, i.e. specification of aims and a selection and grading of content influenced mainly by the language learners themselves. Teacher - based approach puts learner autonomy into effect (De Florio - Hansen, nd : 37- 39).

\section{participants}

A total of 100 Egyptian students:90females and 10 males participated in the study. They are enrolled in the fourth year Faculty of Education, Fayoum University in the second semester 
of the academic year 2014-2015. The participants had been learning English for a period of 16 years.

\section{Instruments for data collection}

\section{1-An EFL learning strategies questionnaire}

This questionnaire aimed at gathering needed information from the students concerning the most commonly used strategies. It is a 55-item questionnaire with a 5-point Likert scale with 5 being "Strongly Agree " and 1 "Strongly Disagree"

This questionnaire was adopted from the study of Abd Alsamie and Ismail (2004) entitled "An investigation of the relationships between EFL pre-service teachers' epistemological beliefs and their learning strategies, teaching practices and foreign language classroom anxiety".

The items of the questionnaire were classified under seven pivots of learning strategies: rehearsal, organization, elaboration, critical thinking, metacognitive, social and affective strategies. The first four pivots pertain to cognitive learning strategies that are deployable when handling the object level of language learning. The metacognitive strategies are those strategies aiming at controlling, guiding and orchestrating cognitive strategies. Social strategies are those dealing with getting 
involved and contributing to effective group dynamics. Affective strategies are those directed at self-encouragement, self-reward and lowering anxiety in language learning situations (Abd Alsamie and Ismail, 2004:9-10).

\section{validity}

To estimate the validity of the learning strategies questionnaire, self validity is used. The self validity of the learning strategies questionnaire was 0.90 .

\section{Scoring}

The summated rating method was used in scoring the list. Students are asked to put a tick $(\mathrm{V})$ to indicate how far the statements are true for them. Each response was associated with a point value "Strongly Agree" was assigned a point of 5, wile "Strongly Disagree" is assigned a point of 1.

\section{Reliability}

A pilot experimentation of the tool was performed on Egyptian majors. Reliability of the learning strategies list was calculated using the internal consistency estimate of reliability. The calculated Cronbach's Alpha was (0.85). 


\section{2- The learner autonomy questionnaire}

This questionnaire aimed at gathering information from the students concerning their autonomy in the learning process.

After specifying the objectives of the questionnaire, its dimensions were identified as follows:

- Responsibility, comprising 14 items.

- Reflection, comprising 8 items.

- Self esteem, comprising 12 items.

- Activation of independent learning strategies, comprising 5 items.

- Self assessment, comprising 9 items.

- Self empowerment, comprising 11 items.

Questionnaire items were preceded by clear and naive instructions to the students to put a tick $(V)$ in the suitable place to match their opinions about each item of the questionnaire.

\section{c- Validity of the questionnaire:}

To estimate the validity of the questionnaire, a group of jury members were asked to read the questionnaire and express their point of view concerning the following criteria:

-Formulation

-Relatedness of each item to its main category

-Change via modifying, adding, replacing, or removing 
The jury members judged the questionnaire to be valid concerning the two above mentioned criteria.

\section{Scoring}

The summated rating method was used in scoring the list.

Students are asked to put a tick $(\mathrm{V})$ to indicate how far the statements are true for them. Each response was associated with a point value "Always" was assigned a point of 5, while "Never" is assigned a point of 1 .

\section{Reliability}

A pilot experimentation of the tool was performed on Egyptian majors. Reliability of the learning strategies list was calculated using the internal consistency estimate of reliability. The calculated Cronbach's Alpha was (0.85).

\section{Data collection procedures}

The study was conducted during the first semester of the academic year 2014-2015 at the end of October. Participants were told that their answers will be dealt with confidentially and are not subject to personal evaluation. After that, they were informed about the procedures and given enough time to respond to the questionnaires. 


\section{Findings}

To find out about the learning strategies used by the fourth year English majors, mean scores and standard deviations are calculated.

\begin{tabular}{|c|c|c|c|c|c|c|c|}
\hline & & Cognitive & trategies & & & & \\
\hline & $\begin{array}{l}\text { Rehearsal } \\
\text { strategies }\end{array}$ & $\begin{array}{c}\text { Organization } \\
\text { strategies }\end{array}$ & $\begin{array}{c}\text { Elaboration } \\
\text { strategies }\end{array}$ & $\begin{array}{c}\text { Critical } \\
\text { thinking } \\
\text { strategies }\end{array}$ & $\begin{array}{l}\text { cognitive } \\
\text { strategies }\end{array}$ & $\begin{array}{c}\text { Social } \\
\text { strategies }\end{array}$ & strategies \\
\hline $\begin{array}{c}\text { Maximum } \\
\text { scores }\end{array}$ & 5 & 5 & 5 & 5 & 5 & 5 & 5 \\
\hline $\begin{array}{l}\text { Mean } \\
\text { scores }\end{array}$ & 3.38 & 3.62 & 3.33 & 3.1 & 2.6 & 3.8 & 3.1 \\
\hline $\begin{array}{l}\text { Standard } \\
\text { deviation }\end{array}$ & 0.84 & 0.78 & 0.84 & 0.83 & 0.78 & 0.84 & 0.83 \\
\hline
\end{tabular}

In general, 4th year students tend to use different learning strategies. The results show an average use of learning strategies

\section{a- Testing the first hypothesis:}

8- Hypothesis one stated that:" There are significant statistical differences between means of scores obtained by the naive and complicated strategies users in all autonomy components in favour of the complicated strategies users ".

Concerning biserial correlation coefficient, the study results show that there is a correlative relationship with a correlation coefficient ( 0.98 )that is statistically significant at (0.01) 
between strategies types (naïve vs. sophisticated) and students' scores in the all autonomy components .

\section{b- Testing the second hypothesis:}

1- Hypothesis one stated that:" There are significant statistical differences between means of scores obtained by the naive and complicated strategies users in responsibility component in favour of the complicated strategies users".

Concerning biserial correlation coefficient, the study results show that there is a correlative relationship with a correlation coefficient ( 0.95 ) that is statistically significant at ( 0 . 01) between strategies types (naïve vs. sophisticated) and students' scores in the first component.

\section{c- Testing the third hypothesis:}

1- Hypothesis three stated that:" There are significant statistical differences between means of scores obtained by the naive and complicated strategies users in reflection component in favour of the complicated strategies users ".

Concerning biserial correlation coefficient, the study results show that there is a correlative relationship with a correlation coefficient ( 0.92 )that is statistically significant at (0.01) between strategies types (naïve vs. sophisticated) and students' scores in the second component. 


\section{d- Testing the fourth hypothesis:}

1- Hypothesis four stated that:" There are significant statistical differences between means of scores obtained by the naive and complicated strategies users in selfesteem component in favour of the complicated strategies users".

Concerning biserial correlation coefficient, the study results show that there is a correlative relationship with a correlation coefficient ( 0.90 )that is statistically significant at (0.01) between strategies types (naïve vs. sophisticated) and students' scores in the third component.

\section{e- Testing the fifth hypothesis:}

1- Hypothesis five stated that:" There are significant statistical differences between means of scores obtained by the naive and complicated strategies users in the activation of independent learning strategies component in favour of the complicated strategies users".

Concerning biserial correlation coefficient, the study results show that there is a correlative relationship with a correlation coefficient ( 0.93 ) that is statistically significant at ( 0 . 01) between strategies types (naïve vs. sophisticated) and students' scores in the fourth component. 
f- Testing the sixth hypothesis:

1- Hypothesis six stated that:" There are significant statistical differences between means of scores obtained by the naive and complicated strategies users in selfassessment component in favour of the complicated strategies users ".

Concerning biserial correlation coefficient, the study results show that there is a correlative relationship with a correlation coefficient ( 0.96 )that is statistically significant at (0.01) between strategies types (naïve vs. sophisticated) and students' scores in the fifth component.

\section{g-Testing the seventh hypothesis:}

Hypothesis seven stated that:" There are significant statistical differences between means of scores obtained by the naive and complicated strategies users in self-empowerment component in favour of the complicated strategies users ".

Concerning biserial correlation coefficient, the study results show that there is a correlative relationship with a correlation coefficient ( 0.88 ) that is statistically significant at $(0.01)$ between strategies types (naïve vs. sophisticated) and students' scores in the sixth component.

Findings show that the complicated strategies users outperformed the naive strategies users in all autonomy 
components especially responsibility, reflection, activation of independent learning strategies and self -assessment. In the light of these results the study hypotheses are affirmed.

\section{Discussion}

The study results show that there are clear differences between the naive and complicated strategies users in all components of learning autonomy. The high scores obtained by the complicated strategies users in the responsibility component show a high level of autonomy as they depend on themselves to plan and monitor their learning process whereas the ones obtained by the naive strategies users show a low level of autonomy as they are not able to decide which strategies to use to learn English language. Also, the high scores obtained by the complicated strategies users in the reflection component reflect a high level of autonomy as they constantly review their learning objectives, strategies and materials, while the ones obtained by the naive strategies users reflect a low level of autonomy as they are less to evaluate and reflect upon their learning process. In addition, the high scores obtained by the complicated strategies users in the activation of independent learning strategies component reflect a high level of autonomy as they show their ability to use different learning strategies, while the ones obtained by the naive strategies users reflect a low level of 
autonomy as they are less to use these strategies. Moreover, the high scores obtained by the complicated strategies users in the self-assessment component reflect a high level of autonomy as they show their ability to identify gaps in their capabilities to memorize and remember new content, while the ones obtained by less autonomous group reflect a low level of autonomy as they frequently find excuses for not getting high marks in tests. The study findings are consistent with Cam and Gu (2013) that concluded that strategy-based instruction improved learners' autonomy in the learning process. In addition, they are consistent with Mlstar (2000) that showed that maximizing the training on learning strategies helped to promote learner autonomy. Moreover, they are in line with Machaal (2013) that confirmed that explicit training in the use of meta-cognitive learning strategies would help new college students to develop both autonomy and responsibility. Also, they are consistent with Huang and Ma (2007) that showed that learners are likely to attribute successful learning of L2 vocabulary mostly to their own efforts rather than to teachers' help as they became more autonomous learners.

\section{Suggested topics for further research}

In the light of the study results, the following topics are provided: 
1- Investigating the relationship between Egyptian learners' use of learning strategies and their attitudes towards English language.

2-Investigating the relationship between Egyptian learners' use of learning strategies and their language skills.

3- Investigating the effect of participants' gender, self-efficacy and motivation ....etc. on their use of learning strategies.

\section{Recommendations}

In the light of the study results, the following recommendations are provided

1- Encouraging learner to be autonomous ones inside and outside the classroom.

2- Emphasizing the importance of the use of learning strategies .

3- Helping students to be aware of their inner abilities and strategies. 


\section{References}

Abd Alsamie, M. F. \& Ismail, A. M. (2004). An investigation of the relationships between EFL pre-service teachers' epistemological beliefs and their learning strategies, teaching practices and foreign language classroom anxiety.

Aliponga , J.; Gamble, C. \& Ando , S. (2011). Verbalization plus automatization plus autonomy: A naive formula for learner autonomy. In D. Gardner (EDs.), Fostering Autonomy in Language Learning (pp 9098). Gaziantep: Zirve University.

Bayat, U.A. (2008). The relationship between autonomy perception and classroom behaviors of English language learners. Paper presented at MA TEFL 20th Anniversary Reunion Conference at Bilkent University. Retrieved from:http://dergiler:ankara.edu.tr/dergiler/27/16 00/17266.pdf.

Chamot, A.U. (2004). Issues in language learn strategies research and teaching. Electronic Journal of Foreign Language Teaching. 1 (1) , 14- 26. 
Chamot, A.U. ; Keatley, C.; Meloni, C.F.; Gonglewski, M. \& Bartoshesky, A. (nd). Developing autonomy in language learners : learning strategies instruction in higher education. Retrieved from National Capital Language Resource Centre. Georgetown University Web site:http://www.nclrc.org/guids/HED/pdf full.pdf

Codesal, M.M. (2000). Learner centeredness in vocabulary learning . Retrieved from: http://dspace .uah.es/dspace/bitstream/handle/10017/947/Lear ner\%20Centredness\%20in\%20Vocabulary\%20Lear ning.pdf?sequence $=1$

De Florio- Hansen , I. (nd). How to become a successful language learner autonomy, styles and strategies revisited. Retrieved from: http://dergiler.ankara.edu.tr/dergiler/27/758/964 1.pdf.

Fedderholdt, M.(1998). Using Diaries to Develop Language Learning Strategies. The Language Teacher. Retrieved from: http:// 
jaltpublications.org/old tlt/files/98/apr/fedderhol

$\underline{\text { dt.h-tml }}$

Griva, E.; Kamaroudis , S. \& Geladari, A. (2009). Young learner's vocabulary strategies employment in a foreign language. Synergies Sub-Est European . 2, 21- 36.

GU, Y. \& Johson, R.K. (1996). Vocabulary learning strategies and language learning outcomes. Language Learning . $46(4), 643-679$.

Hismanoglu, M. (2000). Language learning Strategies in Foreign Language Learning and Teaching. The Internet TESL Journal. VI (8). Retrieved from: http://iteslj.org/Articles/Hismanoglu$\underline{\text { Strategies.html }}$

Huang, H \& Ma, J.H. (2007). The relationships of learning strategy instruction, autonomy, and motivation in L2 vocabulary learning. Retrieved from: http://scholarspace.manoa.hawaii.edu/handle $\not 10125 / 20187$

Lee, C.K. (2010). An Overview of language learning strategies. ARECLS. 7, 132- 152. 
Little, D. (1995). Learning as dialogue: The dependence of learner autonomy on teacher autonomy. System. 23 (2), 175- 181.

Machaal, B. ( 2013). Promoting students' autonomy and responsibility through metacognitive strategies' training. $\quad$ Retrieved from: http://www.academia.edu/login

Mercer,S.(2005). Vocabulary strategy work for advanced learners of English. English Teaching Forum. 43 (2), 24- 34.

Nalkesen, Y. \& Ozek, Y. (2011). The effects of vocabulary strategy training on vocabulary learning and autonomy: A case study o Turkish EFL students. Mediterranean Journal of Humanities. 1 (2), 163- 170.

Nation, P. (1998). Helping learners take control of their vocabulary learning. GRETA. 6 (1), 9- 18.

O' Malley, J.M. \& Chamot, A.U. (1990). Learning Strategies in Second Language Acquisition. Cambridge: Cambridge University press. 
Oxford ,R.L. (1990). Language Learning Strategies: What Every Teacher Should Know. U.S.: Newbury House.

Tassana-ngam, I. (2004). The Effect of Vocabulary Learning Strategies Training on Thai University Students' Word Retention in the Second Language Classroom Ph.D. Dissertation. UK., University of Essex.

Wenden, A.(1991). Learner Strategies for Learner Autonomy. New York: Prentice Hall. 


\section{الكثف عن العلاقة بين استراتجيات التعلم لاى طلاب الجامعة و}

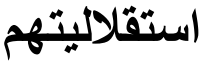

الملخص : يدرس طلاب الفرقة الرابعة بكلية التربية مقررات أكاديمية وتربوية وتعد استقلالية المتعلم احد الأهداف الرئيسة للعملية التعليمية في الجامعة لأنها تمكنهم من الاعتماد على أنفسهم في تحديث معلوماتهم لذا يجب أن تهدف المقررات الدراسية إلى تتمية استقلالية المتعلم.وتهدف الدراسة الحالية إلى الكثف عن العلاقة بين استخدام طلاب الفرقة الرابعة لإستراتجيات التعلم و استقلاليتهم ـ وتكونت عينة الدراسة مسن ( . (1) طالب وطالبة مسن الطلاب المقيدين فى الفرقة الرابعة بكلية التربية شعبة اللغة الانجليزية بجامعة الفيوم ، وقامت الباحثة بتطبيق استبيان لاستر اتجيات التعلم واستبيان لاستقلالية المتعلم على الطلاب عينة الدراسة . وقد تم استخدام معامل الارتباط الثنائي المتسلسل للمعالجة الإحصائية للنتائج. وكثنف النتائج عن معدل استخدام متوسط من قبل الطلاب عينة الدراسة لإستر اتجيات التعلم. و وأسفرت النتائج عن وجود معاملات ارتباط قوية لدى الطلاب مستخدمي الاستراتجيات المعقدة في كل مكونات الاستقلالية وخاصة في أبعاد المسئولية و التأمل وتفعيل الاستراتجيات المستقلة والتقييم الذاتي، وتقدم الدراسة بعض المقترحات للبحوث المستقبلية فى ضوء نتائج الدر اسة. 